SHORT COMMUNICATION

\title{
New records of the invasive macrophyte, Urochloa arrecta extend its range to eastern Brazilian Amazon altered freshwater ecosystems
}

\author{
Ana Luisa Biondi FARES ${ }^{1,2}$, Flávia Alessandra da Silva NONATO ${ }^{1,3}$, Thaísa Sala MICHELAN $1,2,3 * \mathbb{C}$ \\ Universidade Federal do Pará, Instituto de Ciências Biológicas, Laboratório de Ecologia e Conservação (LABECO) e Laboratório de Ecologia de Produtores \\ Primários (ECOPRO), Rua Augusto Corrêa 1, Guamá, 66075-110 Belém, PA, Brazil \\ Universidade Federal Rural da Amazônia, Museu Paraense Emílio Goeldi, Programa de Pós-Graduação em Ciências Biológicas - Botânica Tropical, Belém, PA, Brazil \\ 3 Universidade Federal do Pará, Instituto de Ciências Biológicas, Programa de Pós-Graduação em Ecologia, Rua Augusto Corrêa 1, Guamá, 66075-110 Belém, \\ PA, Brazil \\ * Corresponding author: tsmichelan@ufpa.br; (D) https://orcid.org/0000-0001-9416-0758
}

\begin{abstract}
Invasive species influence the structure and functioning of ecosystems, as they affect native species, significantly decreasing their diversity. Aquatic ecosystems harbor a great biodiversity, and invasive macrophytes significantly affect the native plant communities, causing a cascade effect on other trophic levels. Among invasive macrophytes, Urochloa arrecta is cause for concern in the Neotropics and is found in several regions of Brazil, specially in the southeastern and southern regions. So far the species had been recorded only in the northern state of Amazonas. We report the first record of the species in the state of Pará, in the eastern Brazilian Amazon. We emphasize that identifying sites where this species is invasive is the best strategy to prevent its spread, aiming at the protection and conservation of Amazonian freshwater ecosystems.
\end{abstract}

KEYWORDS: aquatic plants, invasion ecology, grasses, Poaceae, Amazonas state, Pará state

\section{Novos registros da macrófita invasora Urochloa arrecta ampliam sua distribuição a ecossistemas aquáticos alterados na Amazônia Oriental brasileira}

\section{RESUMO}

Espécies invasoras influenciam a estrutura e funcionamento dos ecossistemas, pois afetam as espécies nativas, diminuindo significativamente sua diversidade. Ecossistemas aquáticos abrigam uma grande biodiversidade, e as macrófitas invasoras afetam significativamente a comunidade de plantas nativas, causando um efeito cascata nos diferentes níveis tróficos. Dentre as macrófitas invasoras, Urochloa arrecta é fonte de preocupação nos Neotrópicos, sendo encontrada em diversas regiôes do Brasil, principalmente no sul e sudeste. Na região norte, a espécie só havia sido registrada no Amazonas. Trazemos aqui o primeiro registro desta espécie no estado do Pará, na Amazônia oriental brasileira. Destacamos que a identificação dos locais onde a invasão desta espécie ocorre é a melhor estratégia para que medidas de prevenção que evitem sua dispersão sejam tomadas, visando a proteção e conservação dos ecossistemas aquáticos amazônicos.

PALAVRAS-CHAVE: plantas aquáticas, ecologia de invasão, gramíneas, Poaceae, Amazonas, Pará

Invasive species are a recurrent problem for biodiversity conservation in several ecosystems (Simberloff et al. 2013), as their performance increases with global trade (which makes it easier to cross biogeographical barriers) and the higher tolerance of invasive species to environmental change (D'antonio and Vitousek 1992; Mooney and Cleland 2001). Invasive species are a worldwide concern, as they can change ecosystems through habitat structure, and displacement (McKinney and Lockwood 1999; Alho et al. 2011) or even extinction of native species due to direct biotic interaction (e.g., competition, predation) or indirectly, by altering environmental parameters (Mooney and Cleland 2001; Clavero and García-Berthou 2005; Gallardo et al. 2016).

Freshwater ecosystems have the highest biodiversity per unit area in the planet (Balian et al. 2008), and thus, more species are threatened by invasions in aquatic than in terrestrial ecosystems (Moorhouse and Macdonald 2015). The invasion 
of rivers, lakes, wetlands, and reservoirs by macrophytes is especially harmful due to negative effects on native macrophytes (Madsen et al. 1991; Kovalenko and Dibble 2011) and their role in providing high habitat complexity and keeping biological diversity (Thomaz and Cunha 2010). By affecting native species, invasive macrophytes may cause cascade effects on other trophic levels (Kovalenko and Dibble 2011), reducing animal, plant, and microbial diversity (Lougheed et al. 2008; Thomaz and Cunha 2010), and by affecting structural ecosystem properties (Bunn et al. 1998; Cuassolo et al. 2016).

Grasses can be classified as highly invasive plants and a model group to understand invasion processes, given their resistance to stress and widespread distribution (D'antonio and Vitousek 1992; McKinney and Lockwood 1999). Poaceae are actively moved around by humans, can effectively compete with native species in a wide range of ecosystems, and can reduce native diversity and change ecosystem processes ranging from nutrient cycling to regional microclimate (D'antonio and Vitousek, 1992; McKinney and Lockwood 1999; Amorim et al. 2015). The Poaceae genus Urochloa has already shown great invasive potential, both in terrestrial (Williams and Baruch 2000) and aquatic ecosystems (Thomaz et al. 2009; Michelan et al. 2010).
Urochloa arrecta (Hack. ex T.Durand \& Schinz) Morrone \& Zuloaga is an aquatic species native to Africa, which has infested tropical and subtropical zones around the world (Amorim et al. 2015). It is a perennial grass with long, floating branches, forming thick mats with accumulated stems, leaves and roots. Details for the identification of the species are provided by Lorenzi (2001) under the synonymous name Brachiaria subquadripara. The species can propagate by stolons (Amorim et al. 2015), and through rhizomes or any other fragment that can be carried by water flow (Pott et al. 2011; Michelan et al. 2017). It is a source of concern in hydrodam reservoirs such as Itaipu, in southern Brazil (Thomaz et al. 2009) and natural aquatic environments, such as the Pantanal (Pott et al. 2011), where it reduces native biodiversity (Michelan et al. 2010). The occurrence of $U$. arrecta has already been reported in anthropized areas of several Brazilian states, specially in the northeastern, southeastern, and southern regions, in different biomes, such as the Cerrado savanna and the Atlantic Forest, but also in the northern state of Amazonas, the only one so far in the Brazilian Amazon region (Flora do Brasil 2020; Figure 1).

During a field survey in July 2017, we found extensive $U$. arrecta mats along stream shores and small lakes at several sampling sites in the state of Pará, in Paragominas

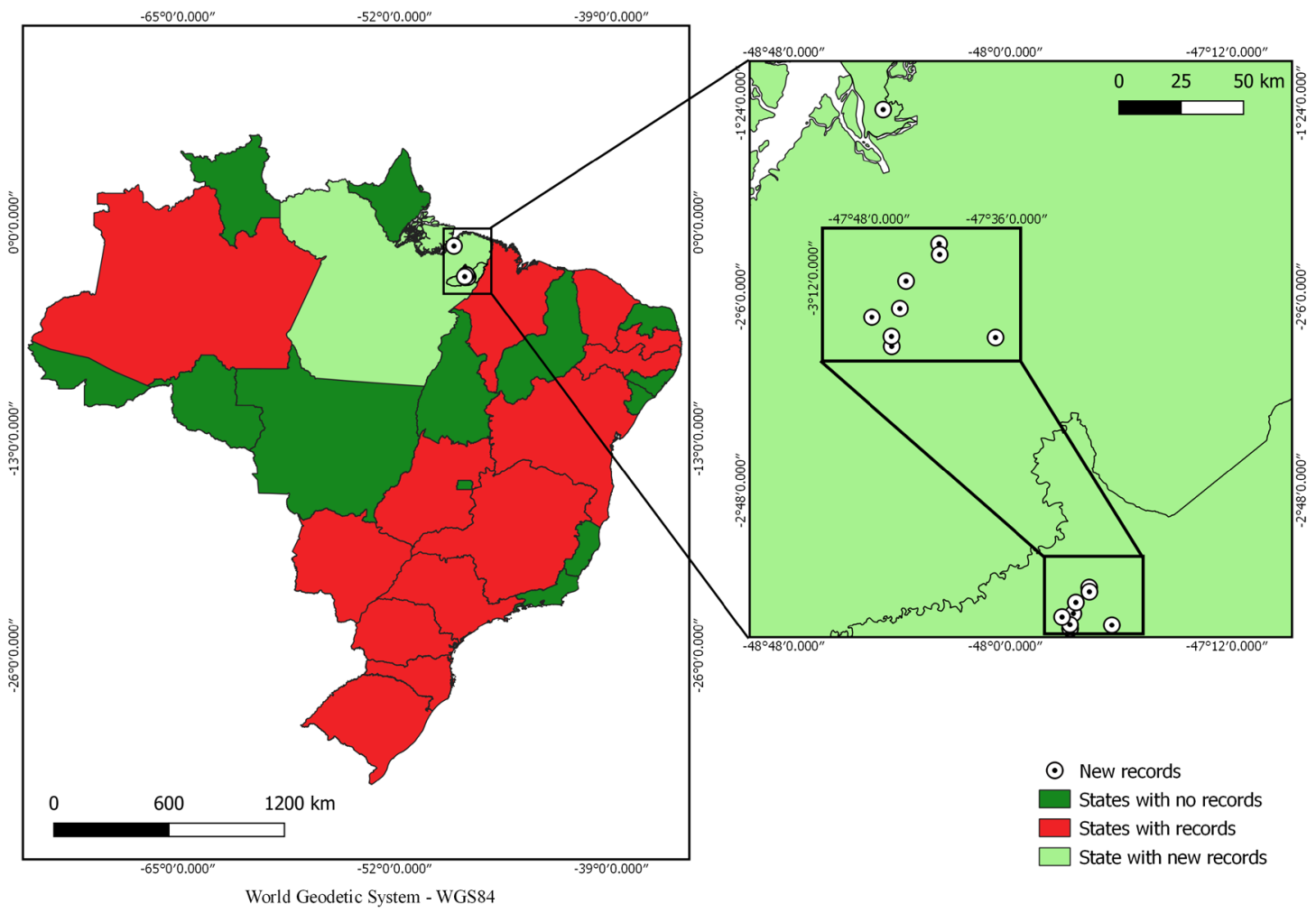

Figure 1. Map showing the new records of Urochloa arrecta in Pará state (light green), Brazil. States in red are those where the species has already been recorded. States in dark green are those with no records of the species to date. Information on species distribution in Brazil from Flora do Brasil (2020) and Michelan et al. (2010) for Paraná state. This figure is in color in the electronic version. 
(02059'45"S, 47०21'10"W) (Figure 2), and in Belém (0127'21'S, 48³0'16"W), in the reservoirs inside Utinga Park, which supply most of the drinkable water to Belém (Figure 2; Table 1). We collected and herborized some plant samples for species identification according to standard herbarium techniques, and all the material is deposited in the Herbarium Felisberto Camargo at Universidade Federal Rural da Amazônia. T.S. Michelan identified the material.

Most sites where we found $U$. arrecta are anthropisized (e.g., pasture, agriculture, mining, and urban areas), and had shorelines cleared of riparian vegetation (Table 1). Considering

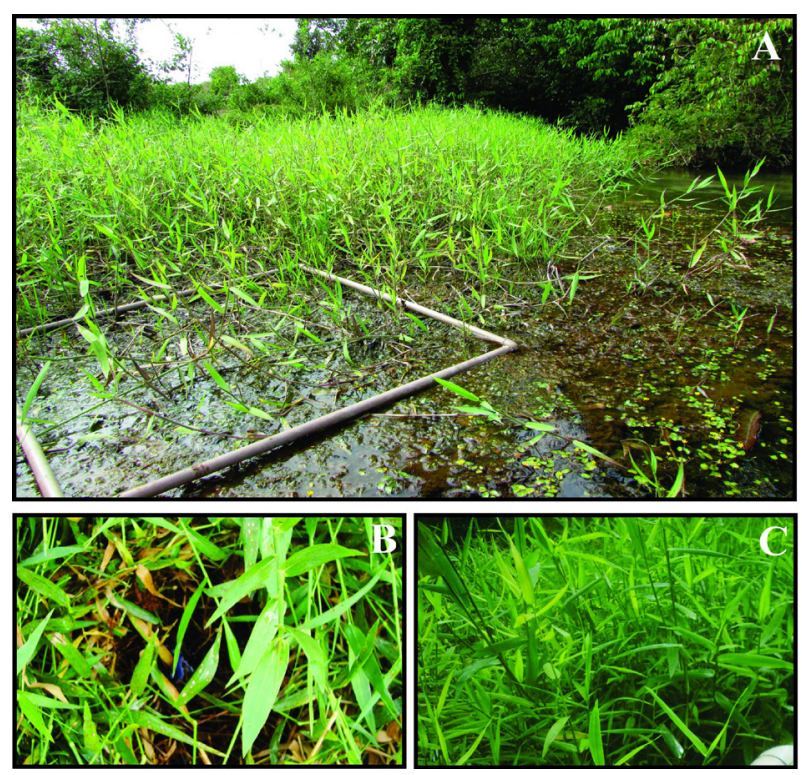

Figure 2. Stream shoreline dominated by Urochloa arrecta in Paragominas, Pará state, Brazil. A - U. arrecta mat; B-C - Details of the species (leaves and stems are glabrous). This figure is in color in the electronic version. the geographical location of our records (Figure 1), it is possible that the species spread into Pará from the neighboring state of Maranhão, as deforestation for pasture and agriculture in Pará created suitable conditions for its dispersal and establishment. Human activity, particularly multiple land use, has likely facilitated the introduction, spreading and stabilization of $U$. arrecta in the surveyed aquatic ecosystems. The expansion of the grass was likely facilitated by decreased shading due to deforestation or forest thinning, increased nutrient availability (e.g. phosphorous and nitrogen) in water and soil, and altered water depth and turbidity. These impacts can disrupt biological processes in native macrophyte species (Vitousek et al, 1997; Kowarik 2003; Lougheed et al. 2008; Gołdyn 2010; Sass et al. 2010; Quinn et al. 2011; Gallardo et al. 2016). The shading by native riparian vegetation can be a limiting factor for the establishment and spreading of $U$. arrecta (Evangelista et al. 2017; Fares et al. 2020), though in Australia the congeneric U. mutica can occur in sites with dense riparian vegetation (Mackay et al. 2010). This means that land-use change (i.e. loss of riparian vegetation) could increase the potential spread of $U$. arrecta, but that the species might also potentially pose a threat to undisturbed habitats, specially in wider rivers whith undisturbed riparian vegetation, where the light penetrates in between the margins. In this case, if fragments/propagules reach freshwater ecosystems that are naturally unshaded, such as floodplain lakes or wetlands connected to streams and rivers that can act as dispersal corridors (Säumel and Kowarik 2010), they can become a threat to native macrophyte communities there.

We emphasize that our records are a matter for concern, considering that the Amazon biome shelters so many important freshwater ecosystems and biodiverse communities, many of which are under constant land use pressure, and therefore already highly vulnerable to biodiversity loss due to

Table 1. Description of the sites where Urochloa arrecta was recorded in Pará state. The degree of invasion was determined according to $U$. arrecta cover percentage inside $1 \mathrm{~m}^{2}$ quadrants, where: 1-25\% = low invasion level, 25-50\%= intermediate invasion level, and 50-100\%= high invasion level.

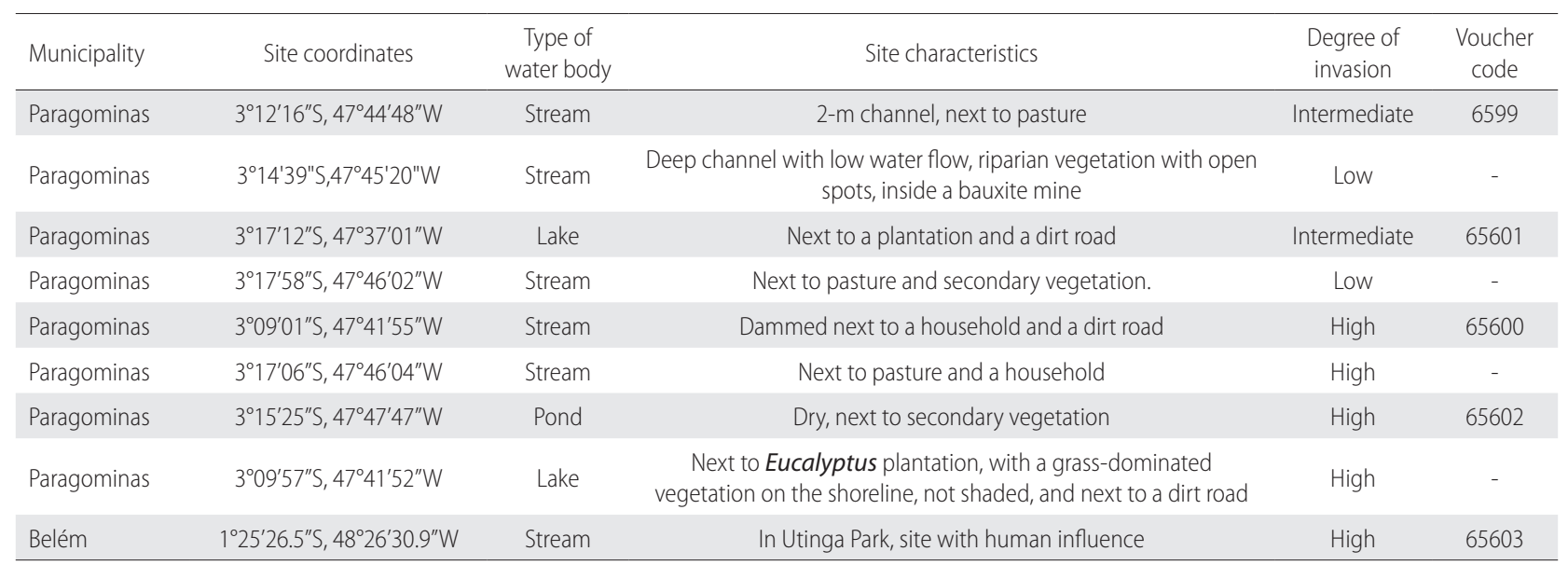


human impact. Early detection is the best strategy to prevent damages by invasive species, as it implies higher probability of eradication and prevention of spread. We recommend eradication of $U$. arrecta from aquatic ecosystems in Pará due to the potential ecological damage this grass may represent to these highly diverse ecosystems.

\section{ACKNOWLEDGMENTS}

We are thankful to Hydro Paragominas Company for supporting the research projects "Monitoring Aquatic Biota of Streams on Areas of Paragominas Mining SA, Pará, Brazil' and "Effects of soil use on diversity and ecophysiology on the riparian vegetation, aquatic macrophytes and plankton in streams and lagoons in mining areas of Paragominas, Pará, Brazil' through the Biodiversity Research Consortium Brazil-Norway (BRC). This paper is number 0008 in the publication series of the BRC. ALBF is thankful to Coordenação de Aperfeiçoamento de Pessoal de Nível Superior - Brasil (CAPES) - Finance Code 001 for her scholarship. FASN is also thankful to Hydro Paragominas Company through the BRC, for her scholarship. We thank the Aquatic Biota field team, especially Calebe Maia for helping with plant collection. We thank Sidinei M. Thomaz for his critical reading, and whose comments improved the final version of our paper.

\section{REFERENCES}

Alho, C.J.R.; Mamede, S.; Bitencourt, K.; Benites, M. 2011. Introduced species in the Pantanal: implications for conservation. Brazilian Journal of Biology, 71: 321-325.

Amorim, S.R.; Umetsu, C.A.; Camargo, A.F.M. 2015. Effects of a non-native species of Poaceae on aquatic macrophyte community composition: a comparison with a native species. Journal of Aquatic Plant Management, 53: 191-196.

Balian, E.V.; Segers, H.; Lévèque, C.; Martens, K. 2008. The freshwater animal diversity assessment: an overview of the results. Hydrobiologia, 595: 627637.

Bunn, S.E.; Davies, P.M.; Kellaway, D.M.; Prosser, I.P. 1998. Influence of invasive macrophytes on channel morphology and hydrology in an open tropical lowland stream, and potential control by riparian shading. Freshwater Biology, 39: 171-178.

Clavero, M; García-Berthou, E. 2005. Invasive species are a leading cause of animal extinctions. Trends in Ecology \& Evolution, 20: 110.

Cuassolo, F.; Navarro, M.B.; Balseiro, E.; Modenutti, B. 2016. Effect of light on particulate and dissolved organic matter production of native and exotic macrophyte species in Patagonia. Hydrobiologia, 766: 29-42.

D’Antonio, C.M.; Vitousek, P.M. 1992. Biological invasions by exotic grasses, the grass/fire cycle, and global change. Annual Review of Ecology and Systematics, 23: 63-87.

Evangelista, H.B.; Michelan, T.S.; Gomes, L.C.; Thomaz, S.M. 2017. Shade provided by riparian plants and biotic resistance by macrophytes reduce the establishment of an invasive Poaceae. Journal of Applied Ecology, 54: 648-656.
Fares, A.L.B; Calvão, L.B.; Torres, N.R.; Gurgel, E.S.C.; Michelan, T.S. 2020. Environmental factors affect macrophyte diversity on Amazonian aquatic ecosystems inserted in an anthropogenic landscape. Ecological Indicators, 113: 1-9.

Flora do Brasil 2020 under construction. Poaceae. Jardim Botânico do Rio de Janeiro. (http://floradobrasil.jbrj.gov.br/reflora/ floradobrasil/FB26027). Accessed on 10 Feb 2020.

Gallardo, B.; Clavero, M.; Sánchez, M.I.; Vilà, M. 2016. Global ecological impacts of invasive species in aquatic ecosystems. Global Change Biology, 22: 151-163.

Gołdyn, H. 2010. Changes in plant species diversity of aquatic ecosystems in the agricultural landscape in West Poland in the last 30 years. Biodiversity Conservation, 19: 61-80.

Kovalenko, K.E.; Dibble, E.D. 2011. Effects of invasive macrophyte on trophic diversity and position of secondary consumers. Hydrobiologia, 663: 167-173.

Kowarik, I. 2003. Human agency in biological invasions: secondary releases foster naturalisation and population expansion of alien plant species. Biological Invasions, 5: 293-312.

Lorenzi, H. 2001. Plantas daninhas do Brasil: terrestres, aquáticas, parasitas e tóxicas. 4th ed. Instituto Plantarum, Nova Odessa, 640p.

Lougheed, V.L.; Mcintosh, M.D.; Parker, C.A.; Stevenson, J.R. 2008. Wetland degradation leads to homogenization of the biota at local and landscape scales. Freshwater Biology, 53: 2402-2413.

Moorhouse, T.P.; Macdonald, D.W. 2015. Are invasives worse in freshwater than terrestrial ecosystems? Wiley Interdisciplinary Reviews: Water, 2: 1-8.

Madsen, J.D.; Sutherland, J.W.; Bloomfield, J.A.; Eichler, L.W.; Boylen, C.W. 1991. The decline of native vegetation under dense Eurasian watermilfoil canopies. Journal of Aquatic Plant Management, 29: 94-99.

Mackay, S.J.; James, C.S.; Arthington, A.H. 2010. Macrophytes as indicators of stream condition in the wet tropics region, Northern Queensland, Australia. Ecological Indicators, 10: 330-340.

McKinney, M.L.; Lockwood, J.L. 1999. Biotic homogenization: a few winners replacing many losers in the next mass extinction. Trends in Ecology \& Evolution, 14: 450-453.

Michelan, T.S.; Thomaz, S.M.; Mormul R.P.; Carvalho, P. 2010. Effects of an exotic invasive macrophyte (tropical signalgrass) on native plant community composition, species richness and functional diversity. Freshwater Biology, 55: 1315-1326.

Michelan, T.S.; Dainez Filho, M.S.; Thomaz, S.M. 2017. Aquatic macrophyte mats as dispersers of invasive plant species. Brazilian Journal of Biology, 26: 1678-4375.

Mooney, H.A.; Cleland, E.E. 2001. The evolutionary impact of invasive species. Proceedings of the National Academy of Sciences, 98: 5446-5451.

Pott, V.J.; Pott, A.; Lima, L.C.P.; Moreira, S.N.; Oliveira, A.K.M. 2011. Aquatic macrophyte diversity of the Pantanal wetland and upper basin. Brazilian Journal of Biology, 71: 255-263.

Quinn, L.D.; Schooler, S. S.; Klinken, R.D.V. 2011. Effects of land use and environment on alien and native macrophytes: lessons 
from a large-scale survey of Australian rivers. Diversity and Distributions, 17: 132-143.

Säumel, I.; Kowarik, I. 2010. Urban rivers as dispersal corridors for primarily wind-dispersed invasive tree species. Landscape and Urban Planning, 94: 244-249.

Sass, L. L.; Bozek, M.A.; Hauxwell, J.A.; Wagner, K.; Knight, S. 2010. Response of aquatic macrophytes to human land use perturbations in the watersheds of Wisconsin lakes, U.S.A. Aquatic Botany, 93: 1-8.

Simberloff, D.; Martin, J-L.; Genovesi, P.; Maris, V.; Wardle, D.A.; Aronson, J.; et al. 2013. Impacts of biological invasions: what's what and the way forward. Trends in Ecology \& Evolution, 28: 58-66.

Thomaz, S. M.; Carvalho P.; Mormul R.P.; Ferreira F.A.; Silveira, M.J.; Michelan T.S. 2009. Temporal trends and effects of diversity on occurrence of exotic macrophytes in a large reservoir. Acta Oecologia, 35: 614-620.
Thomaz, S.M.; Cunha, E.R. 2010. The role of macrophytes in habitat structuring aquatic ecosystem: methods of measurements, causes and consequences on animal assemblages' composition and biodiversity. Acta Limnologica Brasiliensia, 22: 218-236.

Vitousek, P.M.; D'antonio, C.M.; Loope, L.L.; Rejmanek, M.; Westbrooks, R. 1997. Introduced species: A significant component of human-caused global change. New Zealand Journal of Ecology, 21: 1-16.

Williams, D.G.; Baruch, Z. 2000. African grass invasion in the Americas: ecosystem consequences and the role of ecophysiology. Biological Invasions, 2: 123-140.

RECEIVED: $17 / 10 / 2019$

ACCEPTED: 26/01/2020

ASSOCIATE EDITOR: Natália Ivanauskas 